\title{
Immunohistochemical Study of a Newly Defined Oncofetal Antigen (HGR-Ag) in Tumors of the Central Nervous System
}

\author{
Hiroyuki HaSHIMOTO, Toshisuke SAKAKI, Shigeru TSUNODA, \\ Tetsuya MORIMOTO, Toru HOSHIDA, Yoshio HIASA* \\ and Noboru KONISHI* \\ Department of Neurosurgery and *Second Department of Pathology, \\ Nara Medical University, Kashihara, Nara
}

\begin{abstract}
The oncofetal antigen (HGR-Ag) in brain tumors was newly defined using the monoclonal antibody derived from tissue extracts of an anaplastic astrocytoma. The HGR-Ag was purified through sequential chromatography using diethylaminoethyl-Sephadex A-50 and Con-A Sepharose affinity columns. The latter method indicated that HGR-Ag is not a glycoprotein, and Western blot analysis indicated a molecular weight of $80-90 \mathrm{kd}$. Purified antigen was used to produce antibody. This new antibody, designated $\mathrm{H} 1 \mathrm{H} 2$, was shown to be an immunoglobulin $\mathrm{G} 1$ by immunodiffusion assay.

Histological/immunohistochemical studies using the $\mathrm{H} 1 \mathrm{H} 2$ antibody on paraffin and frozen tissue sections showed HGR-Ag to be intracellular rather than membrane-associated. The immunoreactivity of $\mathrm{H} 1 \mathrm{H} 2$ was highest in malignant astrocytomas, glioblastomas, and normal fetal brain tissue. Neurinomas and certain carcinomas of other organs showed lesser, variable reactivity to $\mathrm{H} 1 \mathrm{H} 2$. The strength of the antigen-antibody binding was correlated with the degree of malignancy in human gliomas. $\mathrm{H} 1 \mathrm{H} 2$ bound to fetal brain tissue and undifferentiated neural tumors, but not to normal adult brain tissue, so HGR-Ag is probably a fetal oncoantigen.
\end{abstract}

Key words: monoclonal antibody, oncofetal antigen, malignant glioma

\section{Introduction}

Several monoclonal antibodies (MoAbs) directed at glioma antigens with cross reactivity to gliomas have been reported. ${ }^{8,12,18,21)}$ However, no pure MoAb directed specifically to glioma has yet been established, making clinical applications difficult. However, the use of MoAbs has yielded much information on the biochemistry of malignant tumor cells. Recently, two main clinical approaches to the use of MoAbs have emerged. In immunotherapy, the antibody can damage tumor cells through the immunological response as well as through the direct chemotherapeutic effects of attached anti-tumor agents. ${ }^{10.15)}$ In immunohistochemical investigation, the antibody is useful in the diagnosis of tumors that are difficult to differentiate using morphological characteristics. ${ }^{3,5,24)}$

Here, we report an immunohistochemical study of various brain tumors and malignancies of other organs, normal adult and fetal tissues, and some glioma cell lines using the new MoAb, designated $\mathrm{H} 1 \mathrm{H} 2$, which appears to be specifically directed to the oncofetal antigen, HGR-Ag. Additional biochemical characterization of HGR-Ag was also possible.

\section{Materials and Methods}

\section{Antigen purification}

Fresh tissue from a surgically removed anaplastic astrocytoma was homogenized using a Potter-

Received October 15, 1991; Accepted December 16, 1991

Author's present address: H. Hashimoto, M.D., Department of Neurosurgery, Okanami General Hospital, Ueno, Mie, Japan. 
Elvehjem homogenizer. After centrifugation at $1000 \mathrm{rpm}$ for 10 minutes, the supernatant containing chiefly soluble proteins was separated by diethylaminoethyl (DEAE)-Sephadex A-50 column chromatography into four protein-containing fractions. Protein elution was monitored at $280 \mathrm{~nm}$ with a Perkin-Elmer 55B spectrophotometer. ${ }^{14)}$ The four fractions and supernatants from normal human brain tissue and five malignant gliomas (stored until use at $-80^{\circ} \mathrm{C}$ ) were analyzed using sodium dodecyl sulfate (SDS)-polyacrylamide gel electrophoresis (SDS-PAGE). Aliquots $(100 \mu \mathrm{g})$ of each fraction containing $300 \mu \mathrm{g}$ of protein were analyzed using $7.5 \%$ polyacrylamide gel. Gels were examined to identify bands present in the tumor preparations but not in preparations from normal adult brain tissue. The fraction of the astrocytoma supernatant containing HGR-Ag was further purified using Sephadex G-100 and Con-A Sepharose column chromatography to characterize the antigen.

\section{Production of MoAbs}

$\mathrm{Balb} / \mathrm{c}$ male mice were given subcutaneous injections of the purified HGR-Ag $(424 \mu \mathrm{g})$ suspended in Freund's complete adjuvant $(0.4 \mathrm{ml})$. Seven days later, individuals received an intraperitoneal injection of $1060 \mu \mathrm{g}$ HGR-Ag. Seven days after this, a second intraperitoneal injection of $212 \mu \mathrm{g}$ antigen was given. Three days after the third injection, the mice were killed and the splenocytes were harvested. P3X63Ag8.653 mouse myeloma cells $\left(1.0 \times 10^{7}\right)$ were incubated with mouse immune splenocytes $\left(1.0 \times 10^{8}\right)$ in $0.3 \mathrm{ml}$ of $40 \%$ polyethylene glycol 1540 for 3 minutes at $37^{\circ} \mathrm{C} .{ }^{13)}$ The resulting cells were seeded into microtiter plates at $1 \times 10^{5}$ cells per well and grown in culture medium (hypoxantine $1.0 \times 10^{4} \mathrm{~mol} / \mathrm{l}$, aminopterin $1.0 \times 10^{-5} \mathrm{~mol} / \mathrm{l}$, thymidine $4.0 \times 10^{-5} \mathrm{~mol} / \mathrm{l}$ ) for selection of hybridomas. Two weeks after the fusion procedure, supernatants from each well were analyzed for antibody by the avidin-biotin complex (ABC) immunoperoxidase technique. Cells were diluted and expanded ( 3 cycles) to ensure homogeneity of the selected clones of hybridoma cells. Balb/c mice were then injected with the hybridomas for production of ascites fluids. The resulting ascites were purified using a Sephacryl S-300 column equilibrated with phosphate-buffered saline. The purity and specificity of the antibody was determined using the Ouchterlony immunodiffusion assay.

\section{Tissue samples}

Samples from various brain tumors, malignant tumors of other organs, and normal adult and fetal brain tissue were fixed in $10 \%$ buffered formalin and embedded in paraffin. Brain tumor tissues, stored at $-80^{\circ} \mathrm{C}$ until use, were fixed in periodate-lysineparaformaldehyde solution and immersed in OCT medium (Miles Co., Eikhart, Ind., U.S.A.). ${ }^{(9)}$ Glioma cell lines, SK-MG-1 and SK-MG-4, were cultured for 4 days in tissue culture chamber slides (4802; Miles Co.), then fixed in 50\% methanol and $50 \%$ acetone. These slides, and those prepared from frozen sections, were used for immunohistochemical studies.

\section{Immunohistochemical staining}

Immunohistochemical staining used the $A B C$ method according to the manufacturer's protocol (Vectastain ABC kit; Vecta Lab. Co., Ltd., Burlingame, Cal., U.S.A.). Briefly, MoAb, diluted at 1:200-1:500, was incubated with the tissue for 1 hour at room temperature. The tissue samples were next incubated with biotinylated secondary antibody, then with performed avidin-biotin horseradish peroxidase complex. Antigen was localized by incubation in a peroxidase substrate solution.

\section{Western blot analysis}

The purified proteins separated by SDS-PAGE were transferred electrophoretically to a nitrocellu-

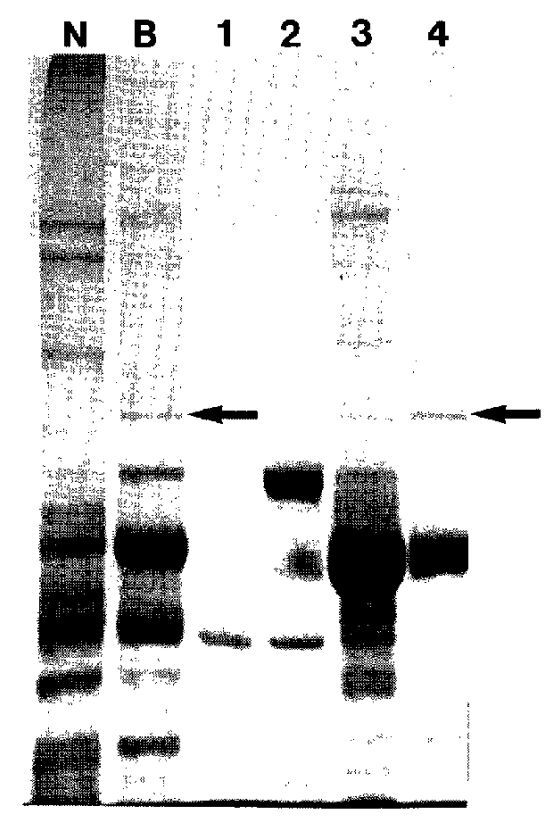

Fig. 1 Electrophoretic analysis using DEAESephadex A-50 column chromatography. Arrows indicate $\mathrm{HGR}-\mathrm{Ag}$ band. $\mathrm{N}$ : normal brain, $\mathrm{B}$ : glioma before chromatography, 1-4: gliomas after chromatography. 
lose membrane and examined immunohistochemically by the $\mathrm{ABC}$ method using $\mathrm{H} 1 \mathrm{H} 2$ antibody. ${ }^{6}$

\section{Results}

\section{Antigen purification}

DEAE-Sephadex A-50 column chromatography of the four fractions derived from human astrocytoma identified a band associated with the tumor (HGR-Ag) in the third and fourth fractions (Fig. 1). The fourth fraction was apparently purer and contained more HGR-Ag. Further chromatography of this fraction using the Sephadex G-100 column achieved no adequate separation of the proteins (data not shown). Therefore, the entire protein-containing band was passed through a ConA Sepharose column, yielding three protein fractions. Only the second fraction contained HGR-Ag by SDS-PAGE analysis (Fig. 2). Addition of 1-0methyl- $\alpha$-D-glucopyranoside indicated that the antigen was not a glycoprotein. Western blot analysis showed the molecular weight (MW) of this HGR-Ag to be $85 \mathrm{kd}$. This fraction was used as the immunogen for production of immune splenocytes in Balb/c mice. Antibody $\mathrm{H} 1 \mathrm{H} 2$ was obtained following fusion of immune splenocytes and mouse myeloma P3X63 Ag8.653 cells as described previously.

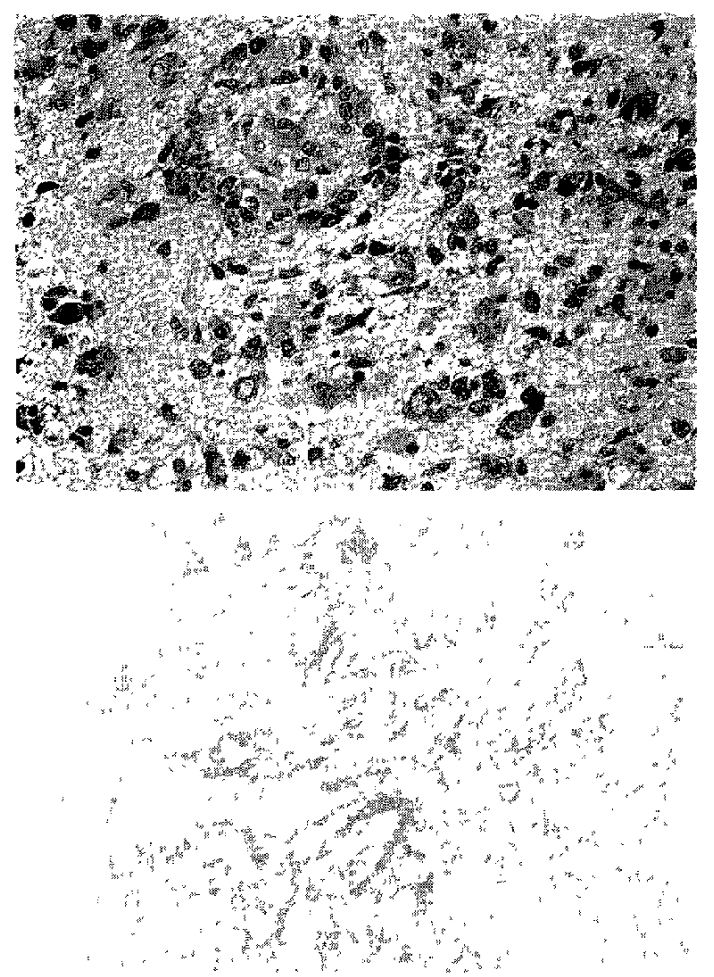

Fig. 3 upper: Astrocytoma grade II. Immunoreactivity in the cytoplasm of tumor cells is much more intensive. Note that the nuclei of tumor cells do not stain. ABC stain, $\times 400$, lower: Glioblastoma. The cytoplasm of the tumor cells is strongly stained. ABC stain, $\times 400$.

\section{Characterization of $\mathbf{H} 1 \mathrm{H} 2$}

Ouchterlony immunodiffusion assay showed the ascites-derived $\mathrm{MoAb} \mathrm{H} 1 \mathrm{H} 2$ to be immunoglobulin G1. Immunohistochemical studies showed that $\mathrm{H} 1 \mathrm{H} 2$ reacted specifically with cytoplasmic components or interstitial tissues in tumors (Fig. 3). In paraffin sections of brain tumors, the immunoreactivities of astrocytoma grades I and II, astrocytoma grades III and IV, and glioblastoma were 45, 85, and $90 \%$ positive staining, respectively (Table 1 ). The data also indicated that the reactivity of $\mathrm{H} 1 \mathrm{H} 2$ to gliomas was positively correlated with malignancy. Thus, although neurinomas demonstrated some reactivity, no medulloblastoma or ependymoma tested exhibited a positive reaction. $\mathrm{H} 1 \mathrm{H} 2$ binding in frozen brain tumor sections generally corresponded to that in paraffin sections. Among malignant tumors in other organs, some hepatomas and small cell carcinomas showed positive antibody-mediated staining, but most tumors did not (Table 2). Some carcinomas showed lesser activity. Glioma cell lines, SK-MG-1 and SK-MG-4, demonstrated positive reac-

Fig. 2 Final fraction after Con-A Sepharose column chromatography. Arrow indicates HGR-Ag band. 
Table 1 Immunoreactivity of $\mathrm{H} 1 \mathrm{H} 2$ in paraffin and frozen sections of human brain tumors

\begin{tabular}{|c|c|c|}
\hline Histology & $\begin{array}{l}\text { No. of positive/ } \\
\text { total cells }\end{array}$ & $\begin{array}{c}\text { Positive } \\
\text { percentage }\end{array}$ \\
\hline \multicolumn{3}{|l|}{ Paraffin section: } \\
\hline \multicolumn{3}{|l|}{ Astrocytoma } \\
\hline grades I and II & $9 / 20$ & 45 \\
\hline grades III and IV & $17 / 20$ & 85 \\
\hline Glioblastoma & $9 / 10$ & 90 \\
\hline Oligodendroglioma & $3 / 10$ & 30 \\
\hline Ependymoma & $0 / 10$ & 0 \\
\hline Medulloblastoma & $0 / 10$ & 0 \\
\hline Neurinoma & $2 / 10$ & 20 \\
\hline Pituitary adenoma & $0 / 8$ & 0 \\
\hline Meningioma & $0 / 10$ & 0 \\
\hline Hemangioblastoma & $0 / 10$ & 0 \\
\hline \multicolumn{3}{|l|}{ Frozen section: } \\
\hline \multicolumn{3}{|l|}{ Astrocytoma } \\
\hline grades I and II & $5 / 10$ & 50 \\
\hline grades III and IV & $9 / 10$ & 90 \\
\hline Glioblastoma & $7 / 7$ & 100 \\
\hline Ependymoma & $0 / 5$ & 0 \\
\hline Neurinoma & $0 / 5$ & 0 \\
\hline Meningioma & $0 / 5$ & 0 \\
\hline
\end{tabular}

Table 2 Immunoreactivity of $\mathrm{H} 1 \mathrm{H} 2$ in paraffin sections of carcinomas of other organs

\begin{tabular}{lc}
\hline \multicolumn{1}{c}{ Organ } & No. of positive/total cells \\
\hline Hepatoma & $4 / 8$ \\
Thyroid carcinoma & $0 / 7$ \\
Esophagus & \\
$\quad$ adenocarcinoma & $0 / 3$ \\
$\quad$ squamous cell carcinoma & $0 / 5$ \\
Stomach & \\
$\quad$ adenocarcinoma & $0 / 7$ \\
Colon & \\
$\quad$ adenocarcinoma & $0 / 6$ \\
Melanoma & $0 / 5$ \\
Renal cell carcinoma & $0 / 5$ \\
Bladder carcinoma & $0 / 5$ \\
Malignant lymphoma & $3 / 10$ \\
Ovary carcinoma & $0 / 3$ \\
Lung & \\
$\quad$ squamous cell carcinoma & $0 / 5$ \\
adenocarcinoma & $0 / 5$ \\
small cell carcinoma & $3 / 5$ \\
Uterus & \\
adenocarcinoma & $0 / 10$ \\
\hline
\end{tabular}

tivities, although the patterns of staining were reticular or granular, in comparison to the more homogeneous patterns observed in paraffin or frozen

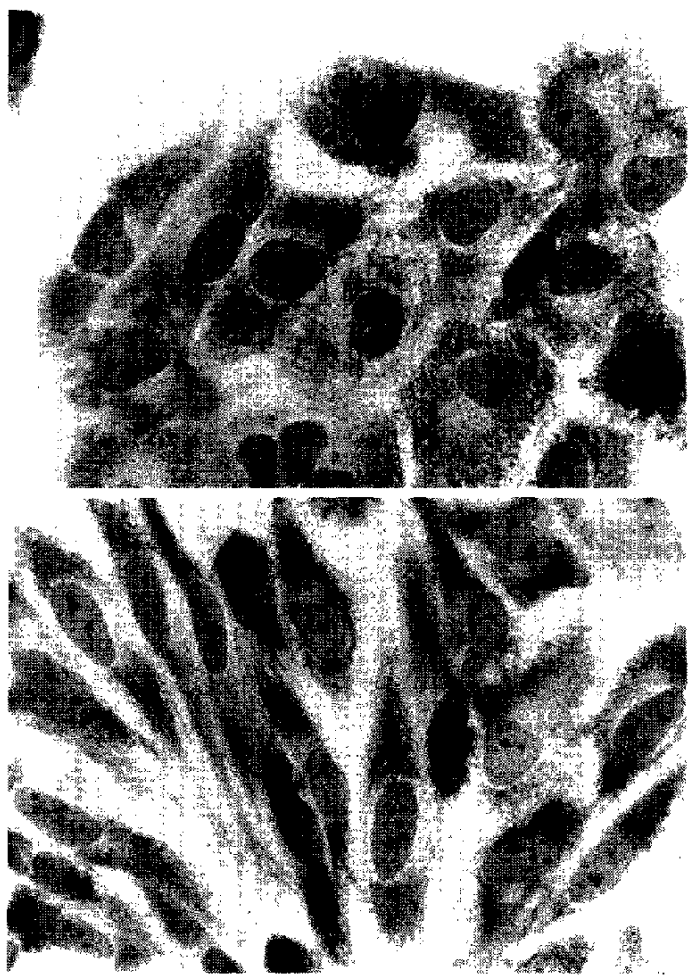

Fig. 4 upper: Glioma cell line, SK-MG-1. The binding of $\mathrm{H} 1 \mathrm{H} 2$ to tumor cells is marked, showing a granular or reticular pattern. ABC stain, $\times 1000$. lower: Glioma cell line, SK-MG-4. The tumor cells are strongly stained like SKMG-1. ABC stain, $\times 1000$.

sections (Fig. 4). With the exception of fetal brain tissue, normal human adult and fetal tissues were non-reactive (Table 3 ).

\section{SDS-PAGE analysis of human gliomas}

Four of the five gliomas examined contained HGR-Ag, shown by the band at the appropriate MW (Fig. 5). These four gliomas showed positive $\mathrm{H} 1 \mathrm{H} 2-$ mediated immunohistochemical staining, while the fifth glioma was negative. Therefore, the immunohistochemical analysis was corroborated by the SDS-PAGE analysis, showing the accuracy of the $\mathrm{ABC}$ technique.

\section{Discussion}

The use of MoAbs to study the central nervous system (CNS) has yielded much information on CNS differentiation, differential diagnosis and microbiology of CNS pathology, particularly of CNS tumors. Antigens expressed by CNS tumors, especially gliomas, are usually in one of four categories: 
Table 3 Immunoreactivity of $\mathbf{H} 1 \mathbf{H} 2$ in paraffin sections of normal human tissues

\begin{tabular}{lcc}
\hline \multirow{2}{*}{ Organ } & \multicolumn{2}{c}{ No. of positive/total cells } \\
\cline { 2 - 3 } & Adult & Fetal \\
\cline { 3 - 3 } Brain & $0 / 5$ & $4 / 5$ \\
Kidney & $0 / 5$ & $0 / 5$ \\
Spleen & $0 / 5$ & $0 / 5$ \\
Thymus & $0 / 5$ & $0 / 5$ \\
Colon & $0 / 5$ & $0 / 5$ \\
Esophagus & $0 / 5$ & $0 / 5$ \\
Bladder & $0 / 5$ & $0 / 5$ \\
Liver & $0 / 5$ & $0 / 5$ \\
Lung & $0 / 5$ & $0 / 5$ \\
Muscle & $0 / 5$ & $0 / 5$ \\
Skin & $0 / 5$ & $0 / 5$ \\
\hline
\end{tabular}
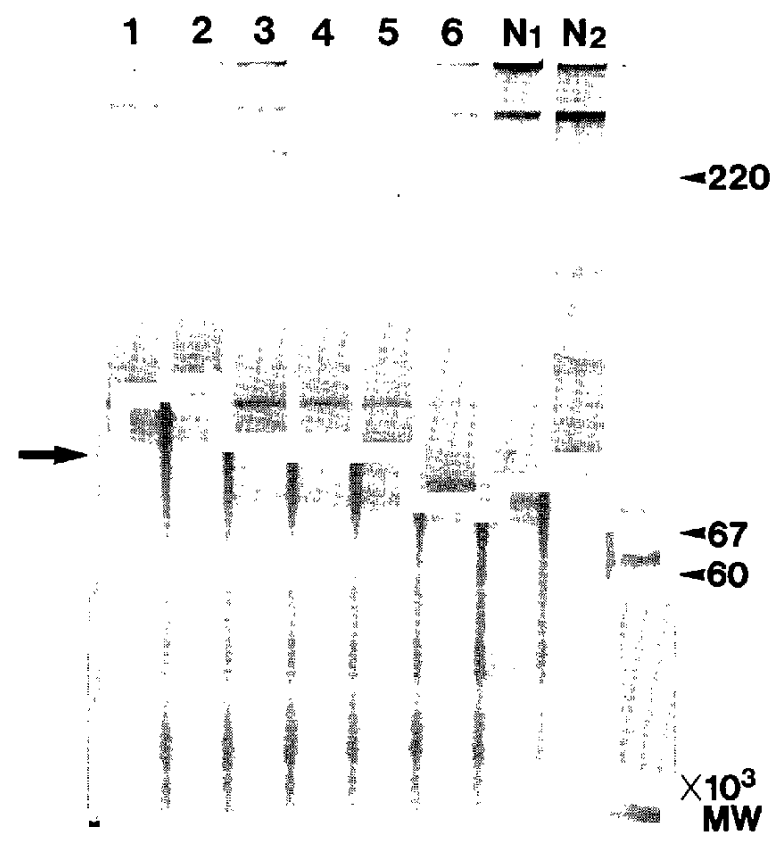

Fig. 5 Electrophoretic analysis of various gliomas. Arrow indicates HGR-Ag band. 1-5: malignant gliomas, 6: edematous brain tissue around glioma $5, \mathrm{~N}_{1}$ : normal frontal lobe, $\mathrm{N}_{2}$ : normal basal ganglia.

1) normal CNS-associated antigens, ${ }^{22,23)}$ 2) shared neural/lymphoid antigens, 3) neuroectodermaloncofetal antigens, or 4) putative tumor-specific antigens. ${ }^{9,25)}$ At present, the most widely used tumor markers for immunohistochemical studies are MoAbs or polyclonal antisera directed against glial fibrillary acidic protein (GFAP) $)^{3,17)}$ and neuronspecific enolase, ${ }^{4,20)}$ all considered normal CNS-asso- ciated antigens and components of cell cytoplasm. Most antigens in the other categories are glycoproteins, glycolipids, or carbohydrates localized on or within the cell surface membranes.

Immunohistochemical investigation has shown $\mathrm{H} 1 \mathrm{H} 2$ binds to a cytoplasmic moiety or moieties, in contrast to the antibodies to GFAP and S-100 protein, which have shown cross reactivity to noncytoplasmic entities. ${ }^{21}$ The high affinity of $\mathrm{H} 1 \mathrm{H} 2$ for malignant gliomas, including anaplastic astrocytomas and glioblastomas, and the non-reactivity in normal adult brain, suggest that the target antigen, presumably HGR-Ag, is also specific to more undifferentiated tissues. However, $\mathrm{H} 1 \mathrm{H} 2$ does not cause immunoreactivity in human ependymoma or medulloblastoma, the latter being one of the most undifferentiated neural malignancies. Neurinomas showed some low-level binding, but all other neural tumors tested were negative. Significantly, $\mathrm{H} 1 \mathrm{H} 2$ shows no apparent binding to normal adult brain tissues, but bound strongly in 12-18-week fetal brains, indicating that HGR-Ag is a fetal antigen or oncoantigen. Glial tumors in the CNS infiltrate the surrounding normal tissue, so such tumors include transformed cells and normal cells of various types. Unless the antigen or antigens are specific to the tumor cells only, some non-specificity of antibodies can be expected. The histogenesis of the cell expressing the antigen would also determine the level of immunoreactivity.

Other CNS-specific antibodies available for immunohistochemical studies include UJ127:11 and UJ13A, both established from as yet unspecified antigens isolated from fetal brain. ${ }^{11}$ UJ13A binds in neural tumors derived from neuroectodermal cells, for example gliomas, ependymomas, meningiomas, and neurinomas. In contrast, UJ127:11 binds to tumors such as medulloblastomas and neuroblastomas. However, both antibodies react with a broad range of normal tissues as well, including adult and fetal brain, adrenal gland, and pancreas., ${ }^{1,11}$

Cell lines have also produced some relatively tissue-specific antibodies. Carrel et $a l_{0}{ }^{8,9)}$ isolated antibodies, designated Mel-4, Mel-14, and Me3-TB7, derived from melanoma cultures and binding to gliomas, neuroblastomas, and melanomas. Liao et $a l .{ }^{16)}$ produced MoAbs 7.51 and 7.60 from melanoma cultures, which react to the same types of brain tumors and to fetal brain. The antigens recognized by these MoAbs are evidently common to both glial and neuronal tumors and suggest a neuroectodermal connection in melanomas. MoAbs such as CG12, AO10, and G13-06, produced by immunizing animals with glioma cell lines, recognize an- 
tigens in gliomas, melanomas, neuroblastomas, and fetal brain-like melanoma-derived MoAbs. However, AO10 and another glioma-derived antibody, AJ8, also show affinity for astrocytomas and epithelial cancers. ${ }^{7}$ These MoAbs differ in that AJ8 binds more to the differentiated and/or GFAP-positive gliomas while AO10 has greater affinity for undifferentiated, GFAP-negative gliomas. $\mathrm{H} 1 \mathrm{H} 2$, in this respect, resembles $\mathrm{AO} 10$, but $\mathrm{H} 1 \mathrm{H} 2$ does not react to tissues of neuroectodermal origin.

This study has further defined the oncofetal antigen, HGR-Ag, by antigen purification from a human astrocytoma, and demonstrated its existence in several tissues by immunohistochemical methods supported by column chromatography and gel electophoresis. A new MoAb to HGR-Ag, H1H2, has a high affinity for malignant gliomas and shows a positive correlation between immunoreactivity and tumor malignancy. The affinity of $\mathrm{H} 1 \mathrm{H} 2$ for normal fetal brain and undifferentiated CNS tumors also suggests that HGR-Ag is a fetal oncoantigen. $\mathrm{H} 1 \mathrm{H} 2$ is another MoAb to human neural tumors, which will help in the differentiation, diagnosis, and biochemical investigation of CNS tumors.

\section{References}

1) Allan PM, Garson JA, Harper EI, Asser U, Coakham H, Brounell B, Kemshead JT: Biological characterization and clinical applications of a monoclonal antibody recognizing an antigen restricted to neuroectodermal tissues. Int $J$ Cancer 31: 591-598, 1983

2) Bignami A, Dahl D: Astrocyte-specific protein and neuroglial differentiation: An immunofluorescence study with antibodies to the glial fibrillary acidic protein. J Comp Neurol 153: 27-38, 1974

3) Bonnin JM, Rubinstein LJ: Immunohistochemistry of central nervous system tumors: Its contributions to neurosurgical diagnosis. I Neurosurg 60: 1121 1131,1984

4) Bonnin JM, Rubinstein LJ, Papaspzpmenos SC, Maragnos PJ: Subependymal giant cell astrocytoma: Significance and possible cytogenetic implications of an immunohistochemical study. Acta Neuropathol (Berl) 62: 185-193, 1984

5) Bullard DE, Bigner DD: Applications of monoclonal antibodies in the diagnosis and treatment of primary brain tumors. J Neurosurg 63: 2-16, 1985

6) Burnette WN: Western blotting: Electrophoretic transfer of proteins from sodium dodecyl sulfatepolyacrylamide gels to unmodified nitrocellulose and radiographic detection with antibody and radioiodinated protein A. Anal Biochem 112: 195-203, 1981

7) Cairncross JG, Mattes MJ, Beresford HR, Albino
AP, Houghton AN: Cell surface antigens of human astrocytoma subsets. Proc Natl Acad Sci USA 79: $5641-5645,1985$

8) Carrel S, de Tribolet N, Gross N: Expression of HLA-DR and common acute lymphoblastic leukemia antigens on glioma cells. Eur J Immunol 12: 354-357, 1982

9) Carrel S, de Tribolet N, Mach JP: Expression of neuroectodermal antigens common to melanomas, gliomas and neuroblastomas. I. Identification by monoclonal antimelanoma and antiglioma antibodies. Acta Neuropathol (Berl) 57: 158-164, 1982

10) Fischer DK, Chen TL, Narayan RK: Immunological and biochemical strategies for the identification of brain tumor-associated antigens. $J$ Neurosurg 68: 165-180, 1988

11) Kemshead JT, Fritschy J, Garson JA, Allan P, Coakham $\mathrm{H}$, Brown S, Asser U: Monoclonal antibody UJ127:11 detects a 220,000-240,000 dal. glycoprotein present on a subset of neuroectodermally derived cells. Int J Cancer 31: 187-195, 1983

12) Kennett RH, Jonak Z, Biochtol KB: Characterization of antibodies with monoclonal antibodies. Prog Cancer Res Ther 12: 209-219, 1980

13) Kohler G, Milstein C: Continuous cultures of fused cells secreting antibody of predefined specificity. Nature 256: 495-497, 1975

14) Laemmli UK: Cleavage of structural proteins during the assembly of the head of bacteriophage T4. Nature 227: 680,1970

15) Lee Y, Bigner DD: Aspects of immunology and immunotherapy and uses of monocional antibodies and biologic modifiers in human gliomas. Neurol Clin 3: 901-917, 1985

16) Liao SK, Clarke BJ, Kwong PC, Brickenden A, Gallie BL, Dent PB: Common neuroectodermal antigens on human melanoma, neuroblastoma, retinoblastoma, glioblastoma and fetal brain revealed by hybridoma antibodies raised against melanoma cells. Eur J Immunol 11: 450-454, 1981

17) Ludwin SK, Kosek JC, Eng LF: The topographical distribution of S-100 and GFA proteins in adult rat brain: An immunohistochemical study using horseradish peroxidase-labeled antibodies. J Comp Neurol 165: 197-208, 1976

18) McComb RD, Bigner DD: Immunolocalization of monoclonal antibody-defined extracellular matrix antigens in human brain tumors. I Neurooncol 3: 181186,1985

19) Mclean T, Nakane PK: Periodate-lysine-paraformaldehyde fixation. $J$ Histochem Cytochem 22: 1077, 1974

20) Said JW, Vimandalal S, Nash G, Shintaku IP, Heusser RC, Sasson AF: Immunoreactive neuronspecific enolase, bombesin and chromogranin as markers for neuroendocrine lung tumors. Hum Pathol 16: 236-240, 1985

21) Schnegg JF, Diserens AC, Carrel S, Accolla RS, de 
Tribolet U: Human glioma-associated antigens detected by monoclonal antibodies. Cancer Res 41: 1209-1213, 1981

22) Trojanowski JQ, Hickey WF: Human teratomas express differentiated neural antigens: An immunohistochemical study with anti-neurofilament, anti-glial filament and anti-myelin basic protein monoclonal antibodies. Am J Pathol 115: 383-389, 1984

23) Trojanowski JQ, Obrocka MA, Lee VMY: A comparison of eight different chromogen protocols for the demonstration of immunoreactive neurofilaments and glial filaments in rat cerebellum using the peroxidase-antiperoxidase method and monoclonal an- tibodies. J Histochem Cytochem 31: 1217-1223, 1983

24) Warecka K: Immunological differential diagnosis of human brain tumors. $J$ Neurol Sci 26: 511-516, 1975

25) Wikstrand CJ, Bigner DD: Chapter 3: Use of monoclonal antibodies in neurobiology and neurooncology, in: Monoclonal Antibodies in Cancer. New Jersey, Humana Press, 1983, pp 365-397

Address reprint requests to: H. Hashimoto, M.D., Department of Neurosurgery, Okanami General Hospital, 1734 Kuwa-machi, Ueno, Mie 518, Japan. 